\title{
Organic mulch sheet formulation as an effort to help plants adapt to climate change
}

\author{
Aniek Iriany ${ }^{1}\left[\right.$ [ Mochammad Chanan ${ }^{2} \cdot$ Gunomo Djoyowasito $^{3}$
}

Received: 24 February 2017 / Accepted: 19 December 2017 / Published online: 29 December 2017

(C) The Author(s) 2017. This article is an open access publication

\begin{abstract}
Purpose This study aimed to discover the precise material composition and thickness (water hyacinth, rice straw, and banana pseudostem) of organic mulch sheet.

Methods This current research was conducted by means of a number of treatments with various material compositions and thickness of organic mulch sheet. Several tests were administered such as chemical analyses on organic mulch sheet, tensile strength, and Vilensky test.

Result Various compositions of materials resulted in various chemical analyses of organic mulch sheet. Organic mulch with the strongest tensile strength was during the treatment of $60 \%$ water hyacinth, $20 \%$ rice straw, and $20 \%$ banana pseudostem, reaching $3.28 \mathrm{~N} / \mathrm{m}^{2}$. The highest sunlight intensity of mulch composition was during the treatment of M4 (50\% water hyacinth, $40 \%$ rice straw, and $10 \%$ banana pseudostem) with no hole and absorbing.

Conclusion The result showed that water hyacinth, rice straw, and banana pseudostem could be used as the materials for organic mulch sheets. They could add organic matters into the soil, have endurance and strength to apply as mulch in crop cultivation, as well as help plants adapt to climate change.
\end{abstract}

Keywords Organic mulch sheet · Organic matters · Tensile strength $\cdot$ Vilensky $\cdot$ Climate change

\section{Introduction}

Mulch is a soil cover that functions to maintain soil temperature and humidity, inhibit the growth of weeds, also lessen soil erosion (Díaz-Pérez and Batal 2002; Kar and Kumar, 2007; Ekinci and Dursun, 2009; Sinkevičienè et al. 2009; Ibarra-Jiménez et al. 2011; Dvořák et al. 2012). In horticulture plantation, both organic mulch and inorganic mulch have been into a common use (Dvořák et al. 2001; George Hochmuth et al. 2002; Kasirajan and Ngouajio 2012; Cowan

Aniek Iriany

aniek55@yahoo.co.id

1 The Department of Agrotechnology, Faculty of Agriculture and Animal Husbandry, University of Muhammadiyah Malang, Malang, Indonesia

2 The Department of Forestry, Faculty of Agriculture and Animal Husbandry, University of Muhammadiyah Malang, Malang, Indonesia

3 The Department of Agricultural Engineering, Faculty of Agricultural Technology, Brawijya University of Malang, Malang, Indonesia
2013; Lakkenborg et al. 2014; Azad et al. 2015). Specifically, in this unstable climate and global warming condition (Wai et al. 2007), mulch is utilized to help plants adapt to climate change by modifying microclimate around the growing plants (Dvořák et al. 2001; Ibarra-Jiménez et al. 2011; Kasirajan and Ngouajio 2012). The following concern would be on the environment modification to optimize the growth of plants so as to improve potential production (Scholes et al. 1997; Peng et al. 2004; Widiatningrum and Pukan 2010; Kalra et al. 2013). The growth and productivity of plants generally are affected by rainfall, temperature, humidity, and soil fertility (Pereira and Nova 2008; Ayinde et al. 2011; Mahmood et al. 2012; Iriany et al. 2013; Nakano et al. 2013; Yaghi et al. 2013). Some previous studies have found that mulch usage increases plant productivity (Siwek et al. 2007; Miles et al. 2012; Haapala et al. 2015).

Mulch has been into a common use in crop cultivation, yet with a number of drawbacks, such as the use of environmentally unfriendly synthetic materials that are hard to degrade (transparent plastic, PHP, etc.), apart from their high price that are less affordable for farmers (O'Brine and Thompson 2010; Coolong 2012; Kasirajan and Ngouajio 
2012; Miles et al. 2012). However, the use of organic mulch from rice straw, litter, and others are unstable at the time. Accordingly, it is urgent to come up with alternative organic materials from the accessible surrounding environment to be made for organic mulch for the farming field with simple technology. Organic mulch requires modification into more effective and efficient forms in usage by modifying it into sheet forms. Besides, the use of paper as mulch has been developed in some patents such as using cellulose fibers with additional materials, cellulosic pulp with biodegradationretarding agent and addition of fertilizer to optimize mulch function (Wright 1936; Pratt and Medford 1955; Yoko et al. 1986; Peter. F et al. 2003). Most of these patents still used additional materials that are inorganic and relatively expensive to increase satisfactory mechanical strength.

An organic material as a renewable resource contains wood or natural fiber called as cellulose. Organic mulch sheet made from fiber can be processed from natural cellulosic source such as kenaf, pineapple leaf fiber, banana fiber, coir, paddy straw, sugarcane, water hyacinth, corn cobs, and many more (Azubuike \& Okhamafe 2012; Bhatnagar et al. 2015; Indriyati et al. 2016; Salleh et al. 2015; Main et al. 2014; Sarika et al. 2014; Teygeler 2000). These materials contain fiber waste similar to the materials for this current research. The use of organic fiber waste such as banana pseudostem, straw, and water hyacinth for the organic mulch sheet will improve soil properties as the combination of papermaking and organic fertilizer (Mawlana et al. 2014; Vidya and Girish, 2014). Natural organic mulch eventually breaks down and adds organic materials to the soil. Degradation or decomposition of organic mulch increases the amount of soil organic carbon (Bajorien et al. 2013). Hence, microbial activity in the soil will increase, especially microbial biomass supporting any enzymatic process in the soil (Jodaugiene et al. 2010; Moreno et al. 2011). The issue about the use of water hyacinth that has the ability to absorb heavy metal and will harm soil microorganism and the crop is not true. Metals such as iron, manganese, chrome, and cadmium were highly concentrated at the roots than other parts of the plant like leaves and stem. Commonly, the highest concentration of heavy metal in water hyacinth plant is in root, followed by leaves and stem, respectively (C.N et al. 2014; Das et al. 2016; Saha et al. 2017). Water hyacinth can be used as fertilizer, fish or animal feed and for mushroom cultivation. It means that water hyacinth can be used as an organic matter added into the soil. Previous researches showed that organic fertilizer from contaminated heavy metal water hyacinth and cow dung (mass ratio 1:5 and 1:1) did not exceed the limit of quantities of heavy metal and can be applied. Besides, compost of water hyacinth has a positive effect on the formation of macro-aggregates of the soil, water holding capacity, cation exchange capacity and non-significant changes in pH occurred (Khan and Sarwar 2002; Nyawira
2016; Sindhu et al. 2017).Water hyacinth commonly used as bio-absorption of heavy metal does not contain heavy metal on high proportion that will damage or affect the soil (Gavrilescu 2004).

With simple technology, this organic mulch sheet is cheaper in price as it recycles wastes, more practical and effective in usage, using simpler technology, environmentally friendly, and in long-term increases soil fertility. Accordingly, it is necessary to discover the precise material composition of organic mulch sheet.

\section{Methods}

The experiment was conducted in the laboratory of the University of Muhammadiyah Malang and in the farming field in Batu, East Java, in the altitude of 1670 meters above sea level. The experiment was done from March to July 2014.

\section{Material}

The making of organic mulch sheet requires the following materials: water hyacinth, rice straw, and banana pseudostem. The tools were: organic mulch sheet molds, a digital scale, scissors, knife, measuring cup, blender, sieve, stove, pan, and caliper.

\section{Experimental design}

This research was conducted by employing a completely randomized design. The treatment experiment included compositions of organic mulch sheet materials with six variations and two thickness (twelve combinations), then repeated three times. The variation of organic mulch sheet compositions included $\mathrm{M}_{1}=40 \%$ water hyacinth:40\% Rice straw:20\% banana pseudostem; $\mathrm{M}_{2}=50 \%$ water hyacinth:20\% Rice straw:30\% banana pseudostem; $\mathrm{M}_{3}=50 \%$ water hyacinth:30\% Rice straw:20\% banana pseudostem; $\mathrm{M}_{4}=50 \%$ water hyacinth:40\% Rice straw:10\% banana pseudostem; $\mathrm{M}_{5}=60 \%$ water hyacinth:20\% Rice straw:20\% banana pseudostem; $\mathrm{M}_{6}=0.60 \%$ water hyacinth:30\% Rice straw: $10 \%$ banana pseudostem. There are two levels of organic mulch sheet thickness, $\mathrm{T}_{1}=0.5 \mathrm{~mm}$ and $\mathrm{T}_{2}=1 \mathrm{~mm}$.

\section{Implementation of the study}

\section{Making of mold}

Preparing Styrofoam and cloth; one hole was made on the Styrofoam with the size of $30 \mathrm{~cm} \times 50 \mathrm{~cm}$; the upper part of Styrofoam was covered by the cloth. 


\section{Preparation of tools and materials}

Preparing water hyacinth, rice straw, banana pseudostem, and necessary tools.

\section{Cutting and weighing}

The total weight of mulch for each combination was $1000 \mathrm{~g}$. Water hyacinth, rice straw, and banana pseudostem were weighted based on the set composition in each treatment before finally being cut into the size of $1 \mathrm{~cm}$.

\section{Pulping}

Water hyacinth was blended for 15 min and banana pseudostems were blended for $20 \mathrm{~min}$ by the addition of water before being squeezed to take the pulp.

\section{Molding}

Molding process started by pouring and flattening the hot pulp into the prepared mold. Then, the pulp in the mold was dried while being steadily pressed to eliminate the water.

\section{Measured variables and data analysis}

The following tests were conducted: chemical analysis of the organic materials ( $\mathrm{C}$ organic, $\mathrm{N}$ total, $\mathrm{C} / \mathrm{N}$ ratio and organic matter), organic mulch sheet tensile strength by Brazilliant test $\left(\mathrm{N} / \mathrm{cm}^{2}\right)$, Vilensky and sunlight exposure intensity tests. Tabulation was then conducted before statistically being analyzed by means of $\mathrm{F}$ Test. To detect the differences among the treatments, BNJ Test in the level of 5\% was conducted. The data were analyzed by means of Minitab version 17 software.

\section{Results and discussion}

The organic mulch sheet was made of water hyacinth, banana pseudostem, and tannery waste. It produced a compact and strong structure (Li et al. 2010; Sutyasmi 2012; Sahari and Buku 2015). The high cellulose content in the water hyacinth and banana pseudostem (over than 60\%) and low lignin content (lower than 5\%) through the delignification process are used to remove the lignin contained in the materials ( $\mathrm{Li}$ et al. 2010; Tumolva et al. 2013; Ramesh et al. 2014).

\section{Chemical analysis}

The results are shown in the following Table 1 about chemical analyses on organic materials for organic mulch sheet in various treatments. From various treatments, it could be seen
Table 1 The results of chemical analyses on organic materials for organic mulch sheet

\begin{tabular}{llcll}
\hline Treatment & C-organic (\%) & N-total (\%) & C/N ratio & $\begin{array}{l}\text { Organic } \\
\text { matter }(\%)\end{array}$ \\
\hline $\mathrm{M}_{1}(40: 40: 20)$ & 27.69 & 10.16 & 3 & 47.90 \\
$\mathrm{M}_{2}(50: 20: 30)$ & 29.67 & 7.96 & 4 & 51.32 \\
$\mathrm{M}_{3}(50: 30: 20)$ & 31.41 & 11.93 & 3 & 54.33 \\
$\mathrm{M}_{4}(50: 40: 10)$ & 32.78 & 5.73 & 6 & 56.71 \\
$\mathrm{M}_{5}(60: 20: 20)$ & 32.89 & 7.8 & 4 & 56.91 \\
$\mathrm{M}_{6}(60: 30: 10)$ & 31.03 & 2.04 & 15 & 53.68 \\
\hline
\end{tabular}

Table 2 The results of tensile strength analyses on composition treatment for organic mulch sheet

\begin{tabular}{ll}
\hline Treatment & $\begin{array}{l}\text { Tensile } \\
\text { strength }(\mathrm{N} / \\
\left.\mathrm{m}^{2}\right)\end{array}$ \\
\hline $\mathrm{M}_{1}(40: 40: 20)$ & 28.1 \\
$\mathrm{M}_{2}(50: 20: 30)$ & 23.2 \\
$\mathrm{M}_{3}(50: 30: 20)$ & 27.5 \\
$\mathrm{M}_{4}(50: 40: 10)$ & 18.8 \\
$\mathrm{M}_{5}(60: 20: 20)$ & 32.8 \\
$\mathrm{M}_{6}(60: 30: 10)$ & 22.1 \\
\hline
\end{tabular}

that treatment M3 (50\% water hyacinth: 30\% rice straw, $20 \%$ banana pseudostem) and M1 (40\% hyacinth: 40\% rice straw, $20 \%$ banana pseudostem) showed the highest $\mathrm{N}$ total of contents compared to that of other treatments. Previous study showed 50\% water hyacinth and 30 and $20 \%$ straw organic mulch sheet composition increased C-organic, $\mathrm{N}$-total, and organic matter compared with $60 \%$ water hyacinth and $30 \%$ straw composition (Iriany et al. 2016). Besides, the nitrogen content of banana pseudostem is the highest than other raw materials. Nitrogen content of water hyacinth, straw, and banana pseudostem in dry matter, respectively, are $0.28 \%$; 0.5-0.8\%; and 0.93-1.87\% (Dobermann and Fairhurst 2002; Abdullah et al. 2014).

\section{Tensile strength}

Based on the test of the mulch tensile strength, it resulted in the following numbers as shown in Table 2. Table 2 showed that the highest tensile strength was during the treatment of M5. Previous researches have shown that $60 \%$ water hyacinth, $20 \%$ straw, and $20 \%$ banana pseudostem composition gained the highest tensile strength value than other treatments (Djojowasito et al. 2007; Indriyati et al. 2016). Water hyacinth has a compact, short, and soft fiber than others, therefore, it contributes more effects on the tensile strength of organic mulch sheet. Besides, the tensile strength of organic mulch sheet is higher than biodegradable paper made (patented) by Peter. F et al. (2003) 


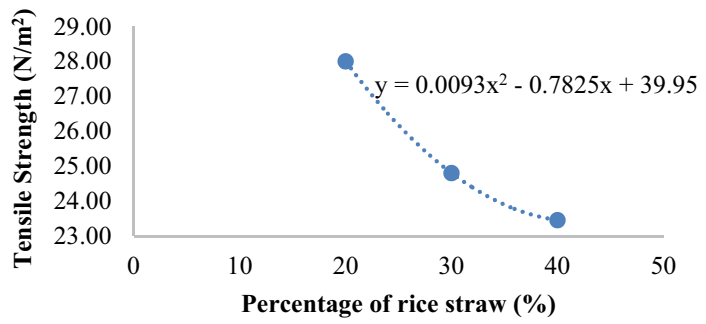

Fig. 1 The correlation between tensile strength and the percentage of rice straw contents in organic mulch sheet

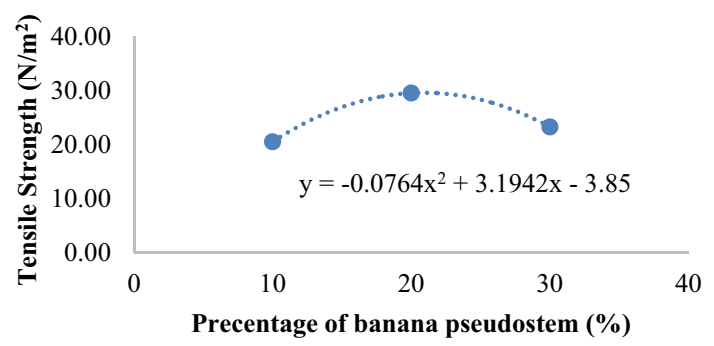

Fig. 2 The correlation between tensile strength and the percentage of banana pseudostem contents in organic mulch sheet

although it is still lower in tensile strength compared to that of fiber composite made from kenaf and pineapple ( $\mathrm{J}$, M.K and W.S 2015).

Figure 1 shows that the increase of rice straw proportion resulted in the decrease of tensile strength. Figure 2 shows the parabolic correlation between the proportion of banana pseudostem and tensile strength and the optimum proportion is shown to be $20 \%$. The correlation between tensile strength and water hyacinth proportion displays an inverse manner from the correlation between tensile strength and banana pseudostem proportion (Fig. 3). The optimum proportions of water hyacinth are 40 and $60 \%$. In each material, the maximum tensile strength was gained from rice straw proportion of $20 \%$, banana pseudostem proportion of $20 \%$, and water hyacinth of $60 \%$. It is similar to the previous study revealing that the highest tensile strength has been gained from 20-30\% banana pseudostem (Djojowasito et al. 2007); also, the other paper exhibited the highest tensile value of the sample at $15 \mathrm{wt} \%$ composition of fiber than 5 and $10 \mathrm{wt} \%$ (MdRadzi et al. 2015). Another paper has shown that the proper comparison of hyacinth plant and coconut coir was 88 and 12\% (Nugroho et al. 2013) also the additional treatment to increase tensile strength was by alkali and enzyme treatments (Tumolva et al. 2013). For pulp from straw, tensile strength could gain $153.10^{5} \mathrm{~N} / \mathrm{m}^{2}$ (Saragi, 2008). Each type of fiber source has its different characteristics as well as its effects on tensile strength of organic mulch sheet. Accordingly, it is crucial to find the proper combination of materials.

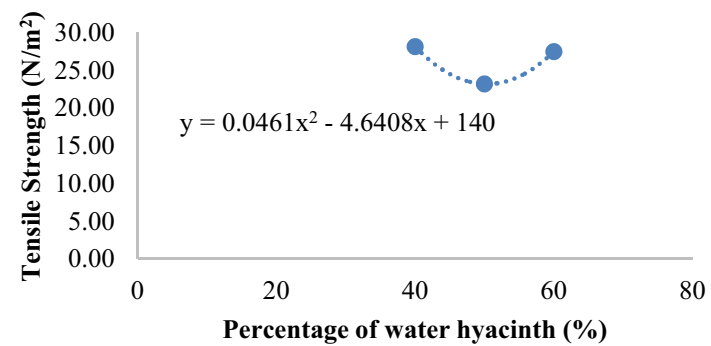

Fig. 3 The correlation between tensile strength and the percentage of water hyacinth contents in organic mulch sheet

Table 3 The result of vilensky test of various organic mulch sheet composition

\begin{tabular}{lllll}
\hline Treatment & \multicolumn{2}{l}{ Sunlight intensity } & \multirow{2}{*}{ Note } \\
\cline { 2 - 4 } & Before & \multicolumn{2}{c}{ After } & \\
\cline { 3 - 4 } & & Wet & Dry & \\
\hline $\mathrm{M}_{1}(40: 40: 20)$ & 15 & 190 & 14 & Without hole, absorbing \\
$\mathrm{M}_{2}(50: 20: 30)$ & 19 & 45 & 22 & Without hole, non-absorbing \\
$\mathrm{M}_{3}(50: 30: 20)$ & 28 & 238 & 20 & Without hole, absorbing \\
$\mathrm{M}_{4}(50: 40: 10)$ & 33 & 298 & 40 & Without hole, absorbing \\
$\mathrm{M}_{5}(60: 20: 20)$ & 8 & 92 & 3 & Without hole, absorbing \\
$\mathrm{M}_{6}(60: 30: 10)$ & 25 & 194 & 24 & Without hole, absorbing \\
\hline
\end{tabular}

\section{Vilensky test}

Table 3 shows that based on Vilensky test, the highest sunlight intensity of mulch composition was during the treatment of M4 (50\% water hyacinth:40\% rice straw: $10 \%$ banana pseudostem). Viewed from the proportion of water hyacinth, the increase in the proportion of water hyacinth could increase sunlight intensity. The picture also portrays that the increase, as well as linear trends, was shown in dry mulch condition. It shows that the increase in the proportion of water hyacinth affects the increase in sunlight intensity (Fig. 4). Fibers from water hyacinth and banana pseudostem that have tied each other prevent the forming of the hole on the mulch (Djojowasito et al. 2007).

Viewed from rice straw proportion used in mulch both with the thickness of $0.5 \mathrm{~mm}$ and $1.0 \mathrm{~mm}$, especially for mulch in wet condition, the quadratic curve with the peak/ maximum cusp was formed in the proportion of $30 \%$. The same case also occurred in the dry condition of mulch. It indicates that the increase and decrease in rice straw proportion affect the decrease in sunlight intensity (Figs. 5 and 6).

Viewed from banana pseudostem proportion used in mulch both with the thickness of $0.5 \mathrm{~mm}$ and $1.0 \mathrm{~mm}$, especially for mulch in wet condition, the quadratic curve tended to decline. In the wet condition, the increase in banana pseudostem proportion affects the decrease in sunlight intensity. 


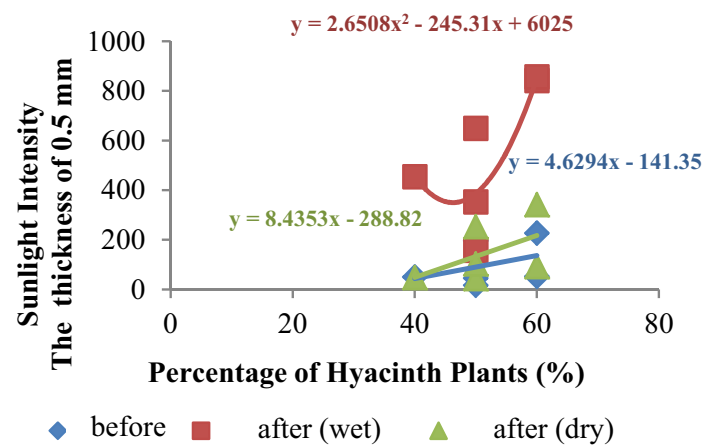

Fig. 4 The correlation between sunlight intensity and the percentage of water hyacinth in $0.5 \mathrm{~mm}$ organic mulch sheet

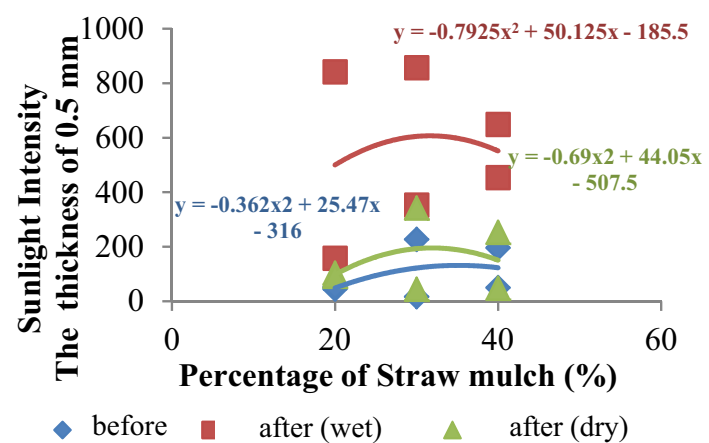

Fig. 5 The correlation between sunlight intensity and the percentage of rice straw in $0.5 \mathrm{~mm}$ organic mulch sheet

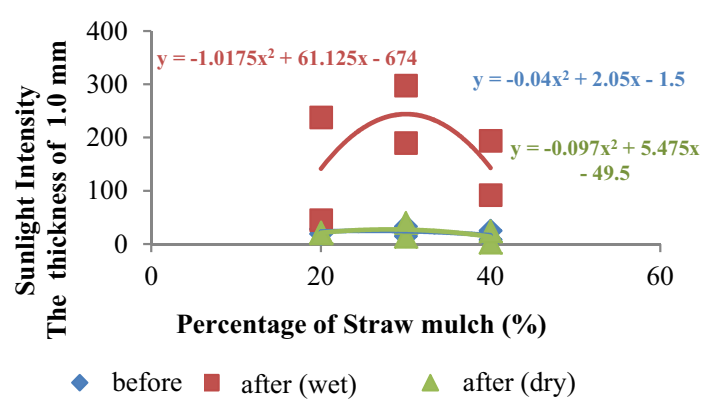

Fig. 6 The correlation between sunlight intensity and the percentage of rice straw in $1.0 \mathrm{~mm}$ organic mulch sheet

However, in the dry condition, the quadratic curve tended to open upward. It is shown that the minimum cusp of sunlight intensity was formed in the proportion of $20-30 \%$. The higher proportion of banana pseudostem resulted in the increase in sunlight intensity (Figs. 7 and 8).

Viewed from hyacinth proportion used in mulch both with the thickness of $0.5 \mathrm{~mm}$ and $1 \mathrm{~mm}$, the quadratic and linear

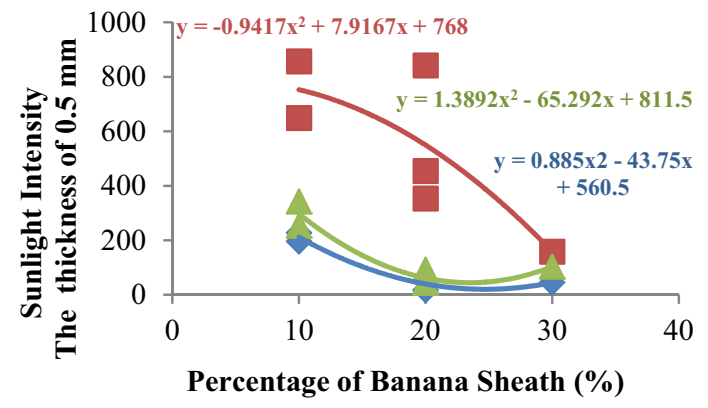

$\checkmark$ before after (wet) $\quad$ after (dry)

Fig. 7 The correlation between sunlight intensity and the percentage of banana pseudostem in $0.5 \mathrm{~mm}$ organic mulch sheet

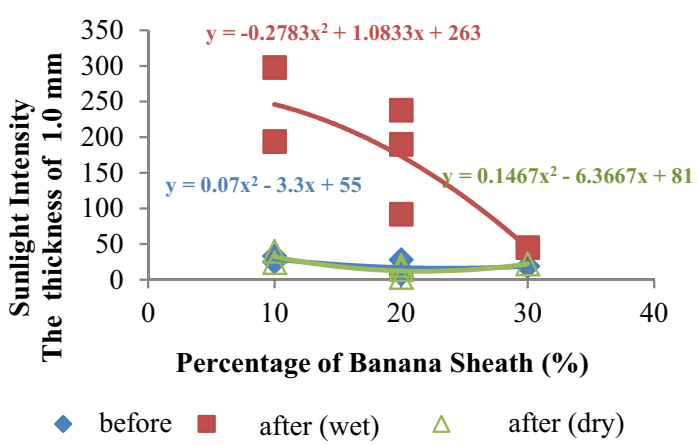

Fig. 8 The correlation between sunlight intensity and the percentage of banana pseudostem in $1.0 \mathrm{~mm}$ organic mulch sheet

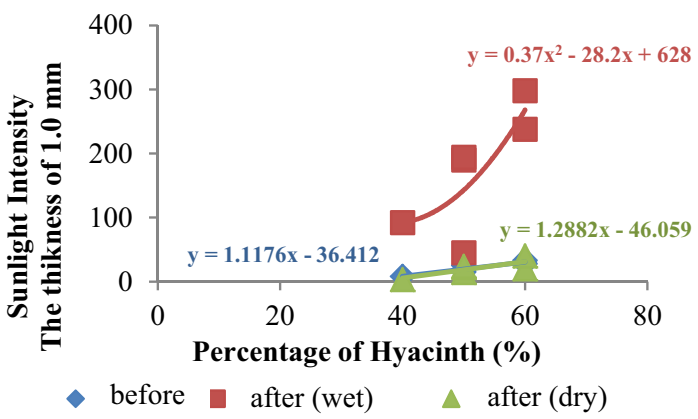

Fig. 9 The correlation between sunlight intensity and the percentage of water hyacinth in $1.0 \mathrm{~mm}$ organic mulch sheet

Table 4 The result of correlation analysis between chemical characteristics of mulch materials and tensile strength of mulch

\begin{tabular}{lrc}
\hline $\begin{array}{l}\text { Chemical characteristics of mulch } \\
\text { materials }\end{array}$ & Correlation & $p$ value \\
\hline C-organic & -0.113 & 0.726 \\
N-total & 0.072 & 0.823 \\
C/N & 0.032 & 0.921 \\
Organic materials & -0.113 & 0.726
\end{tabular}


curve tended to ascend along with the increasing proportion of hyacinth. In the wet and dry conditions, the increase in hyacinth proportion affects the increase in sunlight intensity. The higher proportion of hyacinth resulted in the increase in sunlight intensity (Figs. 4 and 9).

The result of correlation test between chemical characteristics of mulch materials and tensile strength of mulch has shown that chemical characteristics of all materials have $p$ value more than 0.05 . It proves that there is no significant correlation between $\mathrm{C}$-organic contents, $\mathrm{N}$ Total, $\mathrm{C} / \mathrm{N}$, and organic materials and tensile strength of mulch (Table 4).

\section{Conclusion}

The result of this current research has revealed that water hyacinth, rice straw, and banana pseudostem could be used as materials for organic mulch sheet. The best composition has been shown during the treatment of $60 \%$ water hyacinth, $20 \%$ rice straw, and $20 \%$ banana pseudostem seen from tensile strength and endurance towards the water and normal mulch stretch. The best treatment was the composition of $50 \%$ water hyacinth, $40 \%$ rice straw, and $10 \%$ banana pseudostem. Organic mulch with the strongest tensile strength of $32.8 \mathrm{~N}$ resulted during the treatment of $60 \%$ water hyacinth, $20 \%$ rice straw, and $20 \%$ banana pseudostem; also the highest $\mathrm{C}$-organic content was during this treatment that accounted for $32.89 \%$.

Acknowledgement The authors would like to thank University of Muhammadiyah Malang (UMM) for providing necessary facilities to carry out this research. Financial support from DIKTI (Directorate of High Education) for this research is gratefully acknowledged.

Open Access This article is distributed under the terms of the Creative Commons Attribution 4.0 International License (http://creativecomm ons.org/licenses/by/4.0/), which permits unrestricted use, distribution, and reproduction in any medium, provided you give appropriate credit to the original author(s) and the source, provide a link to the Creative Commons license, and indicate if changes were made.

\section{References}

Abdullah N, Sulaiman F, Miskam MA, Taib RM (2014) Characterization of banana (Musa spp.) plantation wastes as a potential renewable energy source. Int J Biol Biomol 8(8):815-819. https://doi. org/10.1063/1.4803618

Ayinde OE, Muchie M, Olatunji GB (2011) Effect of climate change on agricultural productivity in Nigeria: a co-integration model approach. J Hum Ecol 35(3):189-194

Azad, B., Hassandokht, M. R. and Parvizi, K. (2015) 'Effect of mulch on some characteristics of potato in Asadabad, Hamedan', IJAAR , 6(3), pp. 139-147 http://www.innspub.net

Azubuike CP, Okhamafe AO (2012) Physicochemical, spectroscopic and thermal properties of microcrystalline cellulose derived from corn cobs. Int J Recycl Org Waste Agric 1(1):9. https://doi. org/10.1186/2251-7715-1-9

Bajorien K, Jodaugien D, Pupalien R, Sinkevi A (2013) Effect of organic mulches on the content of organic carbon in the soil. Est J Ecol 62(2):100-106. https://doi.org/10.3176/eco.2013.2.02

Bhatnagar R, Gupta G Y, adav, S. (2015) 'A review on composition and properties of banana fibers'. Int J Sci Eng Res 6(5): 143-148 www.ijser.org

Coolong T. (2012) 'Mulches for weed management in vegetable production', Weed Control, Dr. Andrew Price (Ed.) http://cdn.inte chopen.com/pdfs/29919/InTech-Mulches_for_weed_manageme nt_mulches_for_weed_management.pdf

Cowan J S. (2013) The use of biodegradable mulch for tomato and broccoli production: crop yield and quality, mulch deterioration, and grower's perception. Washington State University

Das S, Goswami S, Talukdar ADAS (2016) Physiological responses of water hyacinth, Eichhornia crassipes (Mart.) Solms, to cadmium and its phytoremediation potential. Turkish J Biol 40:84-94. http s://doi.org/10.3906/biy-1411-86

Díaz-Pérez J C, Batal K D (2002) 'Colored plastic film mulches affect tomato growth and yield via changes in root-zone temperature'. J Amer Soc Hort.Sci, 127(1), pp. 127-135. http://journal.ashspubl ications.org/content/127/1/127.short

Djojowasito G, Ahmad AM, Wijaya K (2007) An evaluation of sheet mulch made from a combination of hyacinth (Eichornia crassipes mart. solms) and Musa paradisiaca 1. biomass decomposed with either urea or caustic soda. J Teknol Pertan 8(2):110-118

Dobermann A, Fairhurst TH (2002) 'Rice straw management'. Better Crop Int 16:7-11

Dvořák P, Hajšlová J, Hamouz K, Schulzová V, Kuchtová P, Tomášek J (2001) Black polypropylene mulch textile in organic agriculture. Lucr. Ştiinţifice, Prague

Dvořák P, Tomášek J, Kuchtová P, Hamouz K, Hajšlová J, Schulzová $\mathrm{V}$ (2012) Effect of mulching materials on potato production in different soil-climatic conditions. Rom Agric Res 29:201-209

Ekinci M, Dursun A (2009) Effects of different mulch materials on plant growth, some quality parameters and yield in melon (Cucumis melo L.) cultivars in high altitude environmental condition. Pak J Bot 41(4):1891-1901

Gavrilescu M (2004) Removal of heavy metals from the environment by biosorption removal of heavy metals from the environment by biosorption. Eng Life Sci. https://doi.org/10.1002/elsc.200420026

George Hochmuth, Robert Hochmuth, Steve Olson (2002) 'New technologies in mulching for vegetable production in Florida'. Citrus Veg 1-4

Haapala T, Palonen P, Tamminen A, Ahokas J (2015) Effects of different paper mulches on soil temperature and yield of cucumber (Cucumis sativus L.) in the temperate zone. Agric Food Sci 24:52-58

Ibarra-Jiménez L, Lira-Saldivar RH, Valdez-Aguilar LA, Lozano-Del Río J (2011) 'Colored plastic mulches affect soil temperature and tuber production of potato'. Acta Agric Scand Sect B 61(4):365371. https://doi.org/10.1080/09064710.2010.495724

Indriyati W, Musfiroh I, Kusmawanti R, Sriwidodo, Hasanah AN (2016) Characterization of carboxymethyl cellulose sodium (na-cmc) from water hyacinth (Eichhornia crassipes (mart.) solms) cellulose) growing in Jatinangor and Lembang. IJPST 3(3): 100-110

Iriany A, Syekhfani Soemarno, Suprayogo D (2013) Climate change impact to potato farming in the Java of Indonesia in the mountain range of Batu, East Java of Indonesia. J.App Environ Biol Sci 3(6): $48-55$

Iriany A, Lestari R, Chanan M (2016) Examining organic mulch sheet on the growth and yield of shallot (Allium ascalonicum L.). Malang

Jodaugienè D, Pupalienè R, Sinkevičienė A, Marcinkevičienè A, Žebrauskaitė K, Baltaduonytė M, Čepulienė R (2010) The 
influence of organic mulches on soil biological properties. Zemdirb Agric 97(2):33-40

Kalra N, Suneja P, Mendiratta N, Gupta N (2013) Simulating the impact of climate change and its variability on growth and yield of crops. Clim Chang Environ Sustain 1(1):11-19. https://doi.org/10.5958 /j.2320-6411.1.1.002

Kar G, Kumar A (2007) Effects of irrigation and straw mulch on water use and tuber yield of potato in eastern India. Agric Water Manag 94:109-116. https://doi.org/10.1016/j.agwat.2007.08.004

Kasirajan S, Ngouajio M (2012) Polyethylene and biodegradable mulches for agricultural applications: a review. Agro Sustain Dev 32(2):501529. https://doi.org/10.1007/s13593-011-0068-3

Khan S, Sarwar K (2002) Effect of water hyacinth compost on physical, physico-chemical properties of soil and on rice yield. Pak J Agron 1(2-3):64-65

Lakkenborg H, Campanelli G, Bavec F, Von Fragstein P, Xie Y, Canali S, Titralelli F. (2014) 'Effect of an in-season living mulch on leaching of inorganic nitrogen in cauliflower (Brassica oleracea L. var. botrytis) cropping in Slovenia, Germany and Denmark'. In the 4th ISOFAR Scientific Conference 'Building Organic Bridges' 13-15

Li K, Fu S, Zhan H, Zhan Y, Lucia LA (2010) Analysis of the chemical composition and morphological structure of banana pseudostem. BioResources 5(2):576-585. https://doi.org/10.15376/bior es.5.2.576-585

Mahmood N, Ahmad B, Hassan S, Bakhsh K (2012) Impact of temperature ADN precipitation on rice productivity in rice-wheat cropping system of Punjab province. J Anim Plant Sci 22(4):993-997

Main NM, Talib RA, Ibrahim R, Rahman RA, Mohamed AZ (2014) Suitability of coir fibers as pulp and paper. In Agric Agric Sci Procedia 2:304-311. https://doi.org/10.1016/j.aaspro.2014.11.043

Matindi CN, Njogu PM, Kinyua R, Nemoto Y (2014) 'Analysis of heavy metal content in water hyacinth (Eichhornia crassipes) from Lake Victoria, Kenya'. Int Conf Sustain Res Innov 196-199

Mawlana M, Hossain S, Ferdoushi A (2014) Usefulness of banana (Musa paradisiaca) wastes in manufacturing of bio-products: a review. Agri Int J 12(1):148-158. https://doi.org/10.3329/agric.v12i1.19870

MdRadzi M K F, Sulong A B, Muhamad N, MohdLatiff M A, Ismail N $\mathrm{F}$ (2015) 'Effect of Filler loading and $\mathrm{NaOH}$ addition on mechanical properties of moulded kenaf/polypropylene composite'. Pertanika J Trop Agric Sci 38(4) 583-590. http://www.pertanika.upm.edu.my/

Miles C, Wallace R, Wszelaki A, Martin J, Cowan J, Walters T, Inglis D (2012) Deterioration of potentially biodegradable alternatives to black plastic mulch in three tomato production regions. HortScience 47(9):1270-1277

Moreno MM, Moreno C, Villena J, Mancebo I, Meco R, Campos JA (2011) Effect of different mulches on soil microbiological properties in processing tomato. Res. spain, Geophys

Nakano Y, Higuchi Y, Sumitomo K, Hisamatsu T (2013) Flowering retardation by high temperature in chrysanthemums: involvement of FLOWERING LOCUS T-like 3 gene repression. J Exp Bot 64(4):909-920. https://doi.org/10.1093/jxb/ers370

Nugroho WA, Rahayu FD, Lutfi M (2013) Effect of ingredients formulation of mechanics traits on organic planting bag. J Teknol Pertan 14(2):115-122

Nyawira, M. C. (2016) Analysis of Heavy Metal Content in Water Hyacinth (Eichonia crassipes) from Lake Victoria and Assessment of its Potential as a Feedstock for Biogas Production. University of Nairobi

O'Brine T, Thompson RC (2010) Degradation of plastic carrier bags in the marine environment. Mar Pollut Bull 60(12):2279-2283. http s://doi.org/10.1016/j.marpolbul.2010.08.005

Peng S, Huang J, Sheehy JE, Laza RC, Visperas RM, Zhong X, Centeno GS, Khush GS, Cassman KG (2004) Rice yields decline with higher night temperature from global warming. Proc Natl Acad Sci 101(27):9971-9975. https://doi.org/10.1073/pnas.0403720101
Pereira A, Nova NV (2008) Potato maximum yield as affected by crop parameters and climatic factors in Brazil. HortScience 43(5):1611-1614

Peter F L, Cornellius E C, Potnis P S, Cleveland C S, Knauf G H (2003) 'Biodegradable paper-based agricultural substrate'. United States

Pratt, Medford E R, W. (1955) 'Fertilizer Mulch Paper'. United States

Ramesh M, Ananda TS, Aswin US, Eashwar H, Deepa C (2014) Processing and mechanical property evaluation of banana fiber reinforced polymer composites. Procedia Eng. https://doi.org/10.1016/j.proe ng.2014.12.284

Saha P, Shinde O, Sarkar S (2017) Phytoremediation of industrial mines wastewater using water hyacinth. Int J Phytoremediation 19(1):8796. https://doi.org/10.1080/15226514.2016.1216078

Sahari G N A, Buku A (2015) 'Tensile strength of fiber for some type bananas (Ambon, Kepok, Susu)'. Int J Res Eng Technol 4(8) 23192322. www.ijret.org

Salleh J, Yusoh M.K, Ruzan WS (2015) 'Tensile strength of some naturalfibre composites'. Pertanika J Trop Agric Sci, 38(4), pp. 575-582. http://www.pertanika.upm.edu.my/

Saragi, D. (2008) Forming and characteristic of paper made of mixture of straw pulp and cement bag trace pulp. Universitas Sumatera Utara

Sarika D, Singh J, Prasad R, Vishan I, Varma VS, Kalamdhad AS (2014) Study of physico-chemical and biochemical parameters during rotary drum composting of water hyacinth. Int J Recycl Org Waste Agric 3(3):63. https://doi.org/10.1007/s40093-014-0063-1

Scholes MC, Powlson D, Tian GL (1997) Input control of organic matter dynamics. Geoderma 79(1-4):25-47. https://doi.org/10.1016/S001 6-7061(97)00037-2

Sindhu R, Binod P, Pandey A, Madhavan A, Alphonsa JA, Vivek N, Gnansounou E, Castro E, Faraco V (2017) Bioresource technology water hyacinth a potential source for value addition: an overview. Bioresour Technol 230:152-162. https://doi.org/10.1016/j.biortech .2017.01.035 Elsevier Ltd

Sinkevičienė A, Jodaugienė D, Pupalienė R, Urbonienė M (2009) The influence of organic mulches on soil properties and crop yield. Agron Res 7(1):485-491

Siwek P, Kalisz A, Wojciechowska R (2007) Effect of mulching with film of different colours made from original and recycled polyethylene on the yield of butterhead lettuce and celery. Folia Hortic 19(1):25-35

Sutyasmi S (2012) 'Recycling of shaving waste from tanning industry for art paper'. Maj Kulit karet dan Plast 28(2) 113-121 http://dx.doi. org/10.20543/mkkp.v28i2.114

Teygeler R (2000) Water hyacinth paper. Gentenaar and Torley Publisher, Contributions to a sustainable future

Tumolva T, Ortenero J, Kubouchi M, City Q (2013) Characterization and treatment of water hyacinth fibers for NFRP composites. Int Conf Compos Mater 28:1-11

Vidya S, Girish L (2014) 'Water hyacinth as a green manure for organic farming'. Int J Res Applied Nat Soc Sci 2(6) pp. 65-72. www.impa ctjournals.us

Wai NM, Camerlengo A, Khairi A, Wahab A (2007) A study of global warming in Malaysia. J Teknol 42:1-10

Widiatningrum T, Pukan KK (2010) Growth and production of cauliflower (Brassica oleracea var Botrytis) by organic farming system at lowland climate. Biosaintifika 2(2):115-121

Wright H E (1936) 'Mulch fertilizer paper'. United States

Yaghi T, Arslan A, Naoum F (2013) Cucumber (Cucumis sativus, L.) water use efficiency (WUE) under Plastic Mulch and drip irrigation. Agric Water Manag. 128:149-157. https://doi.org/10.1016/j.agwa t.2013.06.002

Yoko M, Sugiyama K, Osawa J Hara K. (1986) 'Mulching Paper Sheet'. United States

Publisher's Note Springer Nature remains neutral with regard to urisdictional claims in published maps and institutional affiliations. 